on the action of benzoic acid and preservatives and have arrived at conclusions diametrically opposed to those of Dr. Wiley. Your correspondent, however, does not point out the obvious cause for the difference in the results obtained. Dr. Wiley administered the daily amount of preservative inclosed in a capsule in a single dose. Commencing with small quantities he gradually increased the amount until some effect was produced and then argued that because these large doses affected the metabolism, \&c., the preservative was injurious to health. The committee of experts avoided this very obvious fallacy and gave the preservative in divided doses intimately mixed with some article of food and thus observed none of the untoward effects remarked by Dr. Wiley. It is easy to see how by these different methods of procedure different conclusions would be arrived at. Two drachms of common salt administered in a capsule would undoubtedly produce discomfort and in many instances actual vomiting. The same quantity distributed throughout the food taken during the day would have no such effect. The person adopting the former method would conclude that common salt was distinctly injurious to bealth, whilst anyone adopting the latter method would arrive at the opposite conclusion. As to which would be right the common sense of your readers can decide.

I am no advocate for the indiscriminate use of antiseptics, but I like to know the truth even if it does not accord with my preconceived opinions, and as there may be many who have not seen the various reports I have ventured to point out how different members of the profession have been led to contradict each other's results.

I am, Sir, yours faithfully,

JoHN C. THRESH.

Public Health Laboratories, London Hospital Medical

College, London, E., Feb. 15th, 1909

\section{CAPITAL PUNISHMENT IN FRANCE AND ITALY.}

To the Editor of THE LANCET.

SIR,-I have only just read your leading article in THE LAANCET of Jan. 23rd on Capital Punishment in France and Italy, and for this reason $I$ send you rather late a few remarks on it. It seems to me that, admitting the fact that Italy has the "sinister priority in lethal crime," the question remains whether the abolition of capital punishment is the cause of it, or, if not the cause, whether it had an influence on this kind of crime. Capital punishment was abolished in Italy in 1889 and since then the proportion for every 100,000 inhabitants of every kind of homicides is as follows: 1887, $13.4 ; 1888,14 \cdot 4 ; 1889$, $13.3 ; 1890,12 \cdot 0 ; 1891,13 \cdot 0 ; 1892,14 \cdot 4 ; 1893,14 \cdot 1$ $1894,12 \cdot 7 ; 1895,12 \cdot 4 ; 1896,12 \cdot 3 ; 1897,12 \cdot 7 ; 1898$ $11 \cdot 8 ; 1899,11 \cdot 2 ; 1900,10 \cdot 8 ; 1901,9 \cdot 8 ; 1902,9 \cdot 8 ; 1903$, $9 \cdot 4 ;$ and $1904,9 \cdot 1$.

The official statistics of the last three years have not yet appeared. These figures prove that the abolition of capital punishment did certainly not produce an increase of homicides. To say that "an Italian kills an Italian every two hours" is simply disgusting. The number of every kind of homicides in Italy during the last four years quoted above was the following: 1901,$3168 ; 1902,3202 ; 1903$, 3106 and 1904, 3011. Certainly all this is awful, but I am not sure that it means that we have " the sinister priority in lethal crime," because of several nations we do not know the statistics, which are not published. At any rate, it is certain that those peoples which have a less lethal crime than we have enjoy since several centuries a condition of freedom that we have only enjoyed since 1860. I feel quite sure that the question of homicides in Italy is a very complex one, and that it mainly depends on the sentiments of our populations, some of which are very ignorant and have inherited from their ancestors a peculiar feeling that it is not only right but a duty to kill a person on the slightest offences to themselves, their wives, or sisters, \&c. The existence of capital punishment has not the least influence in diminishing such a feeling ; on the contrary, it, remains as a fearful example that a man has the right to kill another. We try to fight and stamp out such a feeling by education, by teaching constantly that homicide is always a crime, and the facts prove that we are on the right way. And I can assure you that we have made such progress that in Italy the revolting executions of Bethune would have been impossible, because a general rebellion of all the population would have prevented them. And we are quite surprised and disgusted that in France these things happened under quite opposite feelings. Do not say that we consider France " the eader of Latin Civilisation."

After all this, allow me to tell you that Italy for this subject has nothing to learn from "the practice and experience of the British Isles." We have a good deal to learn from their teachings in sanitation; we have a great admiration for the steady character of the English people, and we try to show as often as we can our unreserved admiration and what we call simpatia. But we hope that when England will grasp the great truth that " hanging" does not prevent murder, but that other means acting on morality of the people are necessary, she will follow the example of Italy. I am, Sir, yours faithfully,

ChaRLes RUata, M.D.

Perugia, Feb. 7th, 1909. Professor at the University.

*** We must remind Professor Ruata that the statement which he qualifies as " disgusting" was made by an Italian statistician, to whom we referred, and not by ourselves; while the suggestion that in England hanging is used instead of education as a preventive of crime is not in accord with facts. Still, all will approve Professor Ruata's motives in sticking up for his country.-ED. L.

\section{MEDICAL CHARITIES.}

To the Editor of THE LANOET.

SIR,-Most of us doubtless receive from time to time appeals on behalf of charitable institutions, or for some poor brother or sister who is in distress. And your columns are always open to such appeals when the subject is in any way related to the medical profession and is a deserving one. The treasurers of our various medical charities-the British Medical Benevolent Fund, Epsom College, Society for Relief of Widows and Orphans, and THE LANCET Relief Fundmust have heartrending experience of genuine distress, and they must also, to a greater extent than others, share in this distress from the knowledge that their funds are all too small to allow of efficient alleviation.

A plan to raise subscriptions from our profession has occurred to me; and if it should only be half as successful as is the same plan which is carried out on behalf of the Commercial Travellers' Schools much distress would be alleviated and almoners of our charities would be relieved from great anxiety. My attention was drawn to this project last summer, when, going for a brief holiday, I had to break my journey at a small town and stay the night at an unpretentious, but comfortable, inn. On the morrow, whilst having an early breakfast, a small book was courteously handed to me, which on inspection I found to be a register of table money (varying from $2 d$. to $2 s$. $6 d$.) which was expected from, and was paid by, every commercial traveller who visited the inn. I was told that all hotels and inns which are visited by these genial knights of the road possess a similar register and that thereby large sums are annually collected in aid of the Commercial Travellers' Schools at Bushey. I did not reveal my"line of business" but paid my modest shilling to the fund. Well, such a plan, with modifications, could be utilised by the medical profession on behalf of our own charities.

We doctors are as much given apparently to attending dinners (public and semi-public) as any other class of men. Probably during the season alone, say from May to July, there are hundreds of medical men who attend purely professional dinners every week in London alone. Why should not the chairman be given by one or other of these aforesaid charities a book which he could pass round at the end of the feast, and $I$ fear not that each diner, in the fulness of his heart and the generous impulses prompted by an ample meal, will subscribe his sixpence or his shilling and pay it to the chairman. We willingly, and to some extent unnecessarily, give these sums to each waiter who whispers in our ear a "hope that you have been satisfied, sir"; we pay often as much to the cloakroom attendant and to the man who opens the door leading to the street. Now none of these attendants has done for the diner anything but that which has been all paid for in the bill, and the sum we expend in this way 